\title{
The First Legal Mortgagor: A Consumer Without Adequate Protection?
}

\section{Dr Lisa Whitehouse*}

\begin{abstract}
This article contends that the UK government's attempt to create a well-functioning consumer credit market will be undermined if it fails to reform the private law framework relating to the first legal mortgage. Such agreements are governed by two distinct regulatory regimes that are founded upon very different conceptions of the mortgagor. The first, the regulation of financial services overseen by the Financial Conduct Authority, derives from public law and is founded upon a conception of the mortgagor as “consumer”. The other is land law, private law regulation implemented by the judiciary and underpinned by a conception of the mortgagor as "landowner". Evidence suggests that the operation of these two regimes prevents mortgagors from receiving fair and consistent treatment. The current reform of financial services regulation therefore will change only one part of this governance regime and will leave mortgagors heavily reliant upon a regulator that still has to prove itself. What this article argues is that reform of the rules of private law must also be undertaken with the aim of initiating a paradigm shift in the conception of the mortgagor from "landowner" to “consumer”. Cultural shifts of this kind take time but the hope is that this conceptual transformation will occur in time to deter the predicted rise in mortgage possessions.
\end{abstract}

\section{Keywords}

Mortgage Law, Financial Services Regulation, Consumer Protection, Mortgage Credit Directive.

\section{Introduction}

The rhetoric of “consumerism” (Hilton 2003, p. 1) has been prevalent within government housing policy since the early 1980s and has manifested itself in the form of the transference of the responsibility for the provision of housing from the state to the individual within a free market system. Research during the 1990s (Whitehouse 1998; Whitehouse 1998a) argued that the consequent "demotion" of the mortgagor from citizen to consumer had made them vulnerable to the exercise of unaccountable and arbitrary decision making power by mortgagees. What was not appreciated at the time, however, was that while the structural changes necessary to shift the provision of housing to the free market would be achieved, the 
status of the mortgagor in English land law would remain largely unchanged. As the first two sections of this article will demonstrate, the move to a consumerist model of provision has not translated into the mortgagor being conceived of as a "consumer" nor has the first legal mortgage been brought fully within the protective confines of a unified consumer protection regime.

The manner in which land law has viewed the mortgagor has changed over the centuries but rarely has the mortgagor been perceived as a "consumer”. It is interesting to note, for example, that Black and Scott (2000, p. 8) mention transactions involving land "only incidentally” for they do not fit with the traditional focus of consumer protection on goods and services. This cannot be explained simply on the basis that the transaction concerns land because, as is well known, agreements concerning second mortgages fall squarely within the protective borders of consumer credit regulation (Brown 2007; Citizens Advice 2007; Nield 2010). Rather, it derives from the historical development of the modern mortgage device and its crystallisation during the high water mark of the freedom of contract principle (Stewart 1996, pp. 49-50).

As the third section of this article will demonstrate, in contrast to the private law approach, the public law regime adopts a clear vision of the mortgagor as "consumer". This is demonstrated by the government's fundamental programme of reform of the regulation of financial services, bringing both first and second mortgages within the remit of the Financial Conduct Authority (FCA) and consulting on the introduction of the Mortgage Credit Directive on credit agreements for consumers relating to residential immovable property (2014/17/EU) (MCD).

The extent to which these public law measures have impacted on the mortgage market and the private law regime is explored in the fourth section of this article. While the protective measures introduced by the FCA and other provisions (see, for example, the Unfair Terms in Consumer Contract Regulations 1999, the Financial Services and Markets Act 2000 and the Consumer Protection from Unfair Trading Regulations 2008) are to be welcomed, evidence suggests that there is still more work to be done. In particular, mortgagors still do not have sufficient information to allow them to exercise informed choice, are not able to negotiate the terms of their agreement and are subject to onerous terms and conditions that place them at a significant disadvantage (House of Commons Treasury Committee 2009; Stewart 1996, p. 49; Whitehouse 1997; Whitehouse 2011). It is these factors, suggestive as they are of market and 
information failures, which justifies the inclusion of the first legal mortgage within the realm of consumer protection and a cultural shift in the manner in which the private law regime conceives of the mortgagor. The significance of and difficulty in achieving this move, however, is recognised by Stewart (1994, p. 267),

The concept of a consumer, which brings with it some sense of a need to protect against excesses in the market, is not one that merges easily with that of property owner nor with a general political philosophy of a property owning democracy with its connotations of self-sufficiency and release from the shackles of the state.

In calling for greater protection for mortgagors in respect of the first legal mortgage, this article is wary of claims relating to the "commodification” (Forrest and Williams 1984) or “commoditisation” (Fox 2007, pp. 272-274) of housing. The aim, however, in encouraging land law to equate certain aspects of the purchase of land with other consumer products is simply to reverse the somewhat ironic situation prevalent within the current legal framework, which means that mortgagors receive less protection than a consumer purchasing nonessential goods. The argument, therefore, is that mortgagors deserve at least as much protection as would normally attach to the status of consumer. The fifth section of this article will go further, however, by arguing that, given the unique characteristics of the mortgage transaction and the fact that it involves often the purchase of a "home" (Bright 2010; Fox 2007; Gurney 1999; Malpass 1999; Radin 1982; Saunders 1990; Smith 1994), the mortgagor is deserving of targeted and tailored protection, particularly during the possession process. In particular, the aim must be to infuse land law with the key elements of consumer protection, namely, “access, choice, safety, information, equity, redress and representation” (National Consumer Council 1996, p. ii).

In exploring proposals for the reform of mortgage regulation, the penultimate section of this article will argue that the continued operation of two distinct regulatory regimes founded upon different conceptions of the mortgagor will inhibit attempts to create a robust regulatory framework which ensures that all mortgagors are treated fairly. Rather, what is needed is a unified approach in which both regimes conceive of the mortgagor as "consumer”. There are signs that, with the reform of financial services regulation, this may be an opportune moment to initiate a fundamental shift in the legal conception of the mortgagor within land law.

This article will conclude by arguing that while the call for a consumer protection approach in relation to the first mortgagor is not novel (Partington 1993; Stewart 1996, pp. 268-275), it 
has not been made often or loudly enough within academic research. As Smith (2005, p. 31) notes, "while a certain inertia on these points might be expected among politicians and policy makers, it is increasingly hard to justify in the research community.” The time has come therefore to recognise that it is no more appropriate for land law to view the mortgagor as an autonomous individual capable of competing on an equal footing with institutional mortgagees than it is to view smoking as a healthy option. Unless and until land law recognises that both the use and user of mortgage finance have changed, mortgagors will continue to receive less protection than consumers of non-essential goods, a situation that is wholly unjustifiable given the move to a mass home ownership market. In pursuit of this argument, this article will begin by setting the context of the modern mortgage relationship through an account of the "privatisation" (Daunton 1987, p. 5) of the housing market.

\section{The Changing Context of Housing Provision}

The transformation in the UK's housing market, from one dominated by private rented housing in the early twentieth century to one now dominated by home ownership, achieved largely through increased access to mortgage finance, has been well documented elsewhere (Cowan 2011; Cowan and McDermont 2006; Kemeny 1981; Stewart 1994; Whitehouse 1998). For the purposes of this section, it is the structural changes in the provision of housing, achieved largely since 1979 that are significant. While the creation of the mass home ownership market owes much to the willingness of building societies to offer mortgage finance for the purpose of purchasing residential property (Boddy 1980; Cleary 1965; Murie 1998), it was the housing policies of post-war governments and in particular, the Conservative governments of 1979-1997, which “significantly accelerated” (Ford and Burrows 1999, p. 307) its momentum (Cowan 2011; Cowan and McDermont 2006; Kemeny 1981; Stewart 1994; Whitehouse 1998).

Whether one views the housing policies of the Conservative (particular Thatcher) governments as thematic and coherent or ad hoc and reactionary (Stewart 1996, p. 6), it is undeniable that they proved in retrospect to be a master class in combining ideology with functionality. Initiatives such as the "right to buy” (Jones and Murie 2006; Forrest and Murie 1984), the "residualisation" of the public rented sector (Forrest and Murie 1990; Malpass and Murie 1994) and the deregulation of the mortgage market (Kleinman and Whitehead 1988; Cowan 2011, pp. 41-43), contributed not only to the steady growth in the number of owner occupied properties within England and Wales but also to a number of ideological objectives. 
These included the rolling back of the state, a diminution in the power of local councils, enhancing self responsibility among a greater number of occupiers and an increase in the traditionally conservative tenure of home ownership. As Forrest and Murie (1984, p. 60) contend, the Conservative governments were neither subtle nor particularly sophisticated in their pursuit of these ideological objectives,

Rightly or wrongly the Conservative Party believes that the dismantling of the public rental sector is one means of undermining allegiance to socialism. Crudely the equation is that more home-owners means more potential Conservative voters.

As Fox (2007, p. 211) has argued, housing policies over recent decades have tended to promote rather than protect home ownership, a claim supported by the withdrawal during the 1980s and 1990s of state subsidies to home owners and the consequent increase in the number of households left to fend for themselves within the mortgage market (Ford and Quilgars 2001; Stephens et al. 2008; Whitehouse 1998a, p. 204). The Conservative governments’ reduction in public expenditure was, however, unsurprising. Writing in July 1979, two months after the election of Thatcher's first government, Smith and Swann (1979, p. 254) ended their work Protecting the Consumer with a strangely prophetic statement about the new Conservative government, "the emphasis on public expenditure cuts suggests that we may see less rather than more regulation.”

Ultimately, the privatisation initiative, implemented and reinforced within the housing system since 1979, means that housing allocation is determined not by need but by what the occupier can afford (Whitehouse 1998, p. 145), leaving government to play a residual role as facilitator of an effective market regime. As Stewart notes (1996, p. 23), the issue becomes one between consumers and suppliers, not between voters and government. This is a theme that resonates today with the Labour governments of 1997-2010 having reinforced the view of occupiers acting as consumers rather than citizens (Cowan 2011, p. 20) and the Coalition government's decision to re-launch and extend the right to buy (DCLG 2012).

In essence, these policies, coupled with alternative forms of what Cowan describes as “regulating desire” (Cowan 2011, pp. 29-33), have encouraged the perception that home ownership, with its unrivalled security of tenure and financial benefits, is the only choice for the discerning occupier (Stewart 1996). For the vast majority of households encouraged into home ownership, however, the only means of accessing these benefits has been through mortgage finance (Cowan 2011, p. 245). Given the move towards a more consumerist model 
of housing provision, one might have expected the task to have been completed by converting the status of the mortgagor from landowner to consumer. As the following section demonstrates, however, the legal status of the mortgagor has remained largely unchanged since the nineteenth century leading to potentially significant and adverse consequences for the mortgagor.

\section{The Conception of the Mortgagor in Private Law}

Despite the modern acquisition mortgage having many of the hallmarks of a consumer good, with individuals purchasing credit for private use within a market regulated more by competition and self-regulation than law, the purchase of land has rarely been perceived by the private law system as falling within the confines of consumer protection (Scott and Black 2000, p. 8). As Brown (2007, p. 325) indicates, “mortgages for residential property have never really been seen as appropriate for regulation under consumer credit legislation.” The exclusion of the first legal mortgage, however, cannot be explained simply on the basis that the transaction concerns land because agreements concerning second mortgages appear to fall squarely within the protective confines of consumer law.

The distinctive element of the first legal mortgage, however, is that, unlike second mortgages, it involves the purchase of land (Fox 2007, pp. 17-20). In defining the “consumer”, for example, Smith and Swann (1979, p. 18) note that it is not "possible to deal with the subject of house and land purchase, which is subject to a different sort of regulation.” That different sort of regulation is perhaps best described as land law, a subsection of property law that has been infused, over the centuries, with its own distinctive characteristics and principles. The reason as to why land purchase has been afforded its very own system of legal rules and principles derives, in part, from its history and its complexity.

The gradual erosion, since the thirteenth century, of the tenurial system and its replacement by a hierarchy of interests and estates has invested land law with a degree of abstraction that hinders attempts to understand it (Bright, 1998; Gray, and Gray 2009, pp. 64-68). What this section will explore is how this distinctive set of legal rules conceives of the mortgagor, followed in the next section by how this differs from conceptions of the consumer and, perhaps more significantly, how this impacts upon the legal protection afforded to each. The important point to note about the conception of the mortgagor within land law is that it has varied tremendously over the centuries leading to the conclusion that land law would not be averse to further change. 
There has, since the early sixteenth century, been an inherent tension within land law between viewing the mortgagor as a rational and independent actor capable of making an informed choice and a vulnerable individual in need of credit. Between the sixteenth and late nineteenth centuries, this tension was characterised by the conflicting views adopted by the Courts of the Common Law and Equity. The tendency of the Common Law Courts to adopt a formal interpretation of agreements combined with the introduction of the "classical common law mortgage” in the early sixteenth century (Maitland 1936, p. 206; Simpson 1964, p. 225), led to a situation in which, as Simpson notes (1964, pp. 226 - 227),

The common law courts construed mortgage transactions strictly and unsympathetically. If the mortgage provided that the mortgagor was to lose his land through defaulting in payment upon a fixed day then that was that; it mattered nothing that he defaulted by a single day, or that the property was worth infinitely more than the debt.

The presumption underpinning this approach was that the mortgagor was a landowner and the mortgage was a commercial transaction negotiated by parties of equal bargaining strength (Hunter and Nixon 1998, p. 94; Stewart 1996, p. 267). In contrast, the Courts of Equity from the mid-sixteenth century intervened in the contractual relationship between the mortgagor and the mortgagee so as to protect the interests of the former, including the creation of the mortgagor’s “equity of redemption” (Simpson 1964, pp. 227 - 228).

The justification for this degree of interference by the Courts of Equity was founded upon a belief that mortgagors were vulnerable to the demands of the mortgagee. Prior to the late nineteenth century, the legal device of the mortgage was utilised either by merchants as the means of obtaining financial support, or by the poor as the means of obtaining funds which could be used to alleviate their financial difficulties. Mortgagors would use their already acquired land to serve as security for the purposes of the mortgage (Haley 1997, p. 485). It was this aspect of "need” in relation to mortgagors which led Lord Henley LC to note that, "necessitous men are not, truly speaking, free men, but, to answer a present exigency, will submit to any terms that the crafty may impose upon them." ${ }^{1}$ It was considered to be the role of the Courts of Equity, therefore, to protect mortgagors who were party to a contractual agreement in which the balance of power weighed firmly in favour of the mortgagee (Fairest 1980, p. 7). As Haley (1997, p. 483) notes, the history of judicial intervention,

\footnotetext{
${ }^{1}$ Vernon $v$ Bethell (1762) 2 Eden 110 at 113.
} 
has been marked by the uneasy interaction between the laissez-faire attitude of the common law (which upheld the lender's contract and estate rights) and the more protective and tender treatment of the mortgagor in equity (which, in appropriate cases, sought to restrict the exercise of those rights).

The paternalistic approach once adopted by the Courts of Equity towards the mortgagor was gradually eroded during the nineteenth century by a belief in the principle of "freedom of contract”. Stewart contends that this contractual approach led to the denial of the protective supervision once shown by the Courts of Equity, so that, "the flexible and interventionist approach to the mortgagor's position came to an end, never to be regained” (Stewart 1996, p. 49). Atiyah (1995, p. 8) offers an explanation for this transformation in judicial attitudes, "during the nineteenth century, paternalistic ideas waned, as the philosophy of laissez-faire took root. Most educated people, including the judges, took laissez-faire to mean that the law should interfere with people as little as possible.”

This new conception of the mortgage form as, "a commercial transaction negotiated between knowledgeable and equal parties on the terms which should be enforced” (Stewart 1996, p. 50) seems at odds with the changing use made of mortgage finance during this time. The development of the building society movement during the nineteenth century and its willingness to increase access to mortgage finance (Ball 1983, chapter 2; Craig 1986, p. 94), coupled with an unprecedented increase in house building and the simplification of land transfer by the Law of Property Act 1925 (Ball 1983, pp. 29-30; Stewart 1996, p. 25) meant that,

the nature and role of the mortgage in society changed. Advances by private individuals secured on investment property (such as farms and development estates) became less common; most mortgages were granted by institutional lenders on the security of the mortgagor's home (Haley 1997, p. 485).

It was this change in the nature of the mortgage that allowed post-war governments to pursue increasing levels of owner occupation and ultimately to create a mass home ownership market. While recognition of these changes remains scant within land law, there exists one concession to them. It might even be argued to represent one example of where land law adopts a consumer protectionist approach. That concession is s. 36 Administration of Justice Act 1970 which has been described as undertaking "substantial interference with the 
contractual right which the parties have themselves freely negotiated.”2 By virtue of this provision, the district judge is given discretion to suspend an order for possession upon specified payment terms if, "it appears to the court that in the event of its exercising the power the borrower is likely to be able within a reasonable period to pay any sums due under the mortgage" (the term "any sums due" applies only to the arrears outstanding at the time in addition to normal contractual payments, Administration of Justice Act 1973 s 8). Despite its apparent protective import, however, s. 36 serves to support the contention put forward in this article regarding land law's conception of the mortgagor.

According to the Court of Appeal decision in Cheltenham and Gloucester Building Society $v$ Norgan, ${ }^{3}$ district judges, when determining the period over which a mortgagor should be expected to clear their arrears, should have regard to the remaining term of the mortgage. Research (Whitehouse 2011 and 2011a) suggests, however, that the typical period for suspension remains between one and five years. The reason offered by district judges for this restriction on their discretion is that they are concerned to ensure that mortgagors are not subjected to years of ever increasing financial debt. This is due in part to the liability imposed upon a mortgagor for the costs of any legal proceedings undertaken and additional charges while they remain in arrears. District judges, therefore, believe that a period shorter than that of the remaining term of the mortgage is in the best interests of the mortgagor. In addition, s. 36 is only available to those mortgagors who have the financial means necessary to meet the affordability test established under the section. Any other factors, including the presence of children, disability, ill-health or relationship breakdown do not feature within the legislation (Bright and Whitehouse 2014, p. 36).

District judges are also reluctant to intervene in the issue of costs. According to the Practice Direction Part 48 on costs (s. 50.3(2)), 'where there is a contractual right to the costs the discretion should ordinarily be exercised so as to reflect that contractual right.' For this reason, district judges feel unable to award costs against a mortgagee given that the issue has been contractually agreed.

An additional layer of protection has been added to the process as a result of the Pre-Action Protocol for Possession Claims Based on Mortgage or Home Purchase Plan Arrears in

\footnotetext{
${ }^{2}$ [1996] 1 All ER 449, at 458C.

${ }^{3}$ Cheltenham and Gloucester Building Society v Norgan [1996] 1 All ER 449, at 458C.
} 
Respect of Residential Property (the Protocol) ${ }^{4}$ which seeks to ensure that the parties "act fairly and reasonably” with each other in addressing any concerns relating to the mortgage (para. 2.1). This includes giving the borrower a reasonable period of time to consider a proposal for repayment of the arrears (para. 5.6), the consideration of options such as extending the mortgage term or capitalising the arrears (para. 7.1), and advising the borrower to contact the housing department of the local authority and directing them to independent debt advice (para. 5.3). The Protocol applies equally to all residential mortgages (para. 3, it does not cover "buy-to-let” loans as these are regarded as commercial transactions). Compliance with the Protocol should be checked by the court should the mortgagee initiate proceedings in the county court for possession. While there are no sanctions for noncompliance, the judge may adjourn the hearing to allow the mortgagee an opportunity to remedy the omission (Whitehouse 2009; Bright and Whitehouse 2014, p. 26).

Despite its apparent protective qualities, s. 36 AJA 1970 and the possession process generally reinforces the conception of the mortgagor as a largely equal player within the mortgage relationship. The reason for this is that it is influenced heavily by the mortgagee's contractual rights and financial interests, ensuring that payments are maintained and costs secured. Any concerns regarding the mortgagor's potential vulnerability as a consumer or the social implications of repossession simply do not feature.

Despite the fundamental changes in the nature of housing provision, the use made of the mortgage device and the number and type of households accessing mortgage finance, modern land law and its conception of the first legal mortgagor as a rational contracting party to a commercial transaction, even post-1979, has remained largely unchanged (Whitehouse 2009; Whitehouse 2011). One possible explanation for this is provided by Gray and Gray who argue that a more balanced approach to the interests of both parties to a first legal mortgage is required given that (to summarise) the modern mortgagor is no longer needy and the modern mortgagee is no longer greedy (Gray and Gray 2009, pp. 720-721). Another is that, if households are to continue to enjoy access to home ownership then, it is necessary to ensure a steady flow of mortgage finance by protecting the interests of the mortgagee (Fox 2007, pp. 88-92). Evidence in support of the contention that the first legal mortgagor is perceived as less vulnerable than other consumers is offered by an account of the different regimes that regulate first and second mortgages, a distinction that is well rehearsed but which nonetheless

\footnotetext{
${ }^{4}$ See http://www.justice.gov.uk/courts/procedure-rules/civil/protocol/prot_mha.
} 
continues to expose the differing perceptions of the mortgagor dependent on the nature of the agreement (Brown 2007; Citizens Advice 2007; Nield 2010).

\section{First v Second Mortgages}

The current regulatory framework is made complex by the distinction drawn between first legal mortgages, “regulated mortgage contracts” (Financial Services and Markets Act 2000 (Regulated Activities) Order 2001 s. 61(3); PERG 4.4.1G) and second mortgages. The development of this framework, however, is instructive in terms of highlighting the different approach adopted towards mortgagors dependent upon whether the agreement constitutes a first or second mortgage. In particular, it is possible to argue that the regulation of second mortgages has always adopted a much more consumer focused approach. This was made evident in the report of the Crowther Committee, established to review UK consumer credit law and the forerunner of the Consumer Credit Act 1974 (CCA 1974). As Brown (2007, p. 318) notes,

The Crowther Committee had made it clear in their Report in 1971 that they regarded credit for the purchase of a private house as already adequately protected by other regulation. A second mortgage on residential property where the loan was for consumption purposes was, however, another matter. Here, the Committee felt special "protection" was required and this is an attitude that endures...

The enhanced protection afforded to second mortgages is justified on the basis that mortgagors within the secondary mortgage market are more vulnerable to exploitation at the hands of “sub-prime mortgagees” (for a definition see Stephens and Quilgars 2007, pp. 3-4; Munro et al. 2005, pp. 1-3). The assumption, quite simply (and quite perversely given that home ownership is supposed to give rise to enhanced credit worthiness), is that those securing loans against their existing land can seek credit from a wider range of providers including sub-prime lenders and "it is here that borrowers stand most in need of legal protection, being almost by definition 'poorer risk' borrowers who cannot obtain loan facilities from one of the institutional lenders” (Gray and Gray 2009, p. 736). A view supported by the FCA (2014, para. 1.13),

Our analysis indicates that consumers are subject to similar, and in some areas heightened, risks compared to those in the first charge market, particularly given the predominance of second charge mortgages taken to consolidate debt. The degree of 
risk is illustrated by arrears rates for second charge mortgages, which are significantly higher than for first charge mortgages.

The extra protection for second mortgagors called for by the Crowther Committee was introduced in the form of the CCA 1974 which originally required mortgagees of loans of less than $£ 25,000$ to seek possession through the courts (CCA 1974, s. 126) and afforded district judges discretion to vary the terms of the loan or to impose a time order in order to allow the mortgagor more time to repay any arrears (CCA 1974, s. 129). By virtue of s. 16(6C) CCA 1974 (inserted by the Financial Services and Markets Act 2000 (Regulated Activities) Order 2001, now replaced by s. 60C(2) FSMA 2000), regulated mortgage agreements were made exempt from the vast majority of the provisions of the CCA 1974, the assumption being that they were regulated sufficiently by alternative provisions (discussed further below). Despite this, the question over the extent to which first legal mortgages fall within the ambit of the CCA 1974 has vexed scholars and practitioners alike for decades (Brown 2007; Citizens Advice 2009).

There were two aspects of the CCA 1974 which appeared to impact on first legal mortgages and regulated mortgage agreements. The first concerned the courts power to re-write “extortionate credit bargains” (ss. 137-140 CCA 1974) which, unlike most of the other provisions of the CCA 1974 applied to all mortgages (s. 16(7A) CCA 1974). The success of these original provisions, however, proved to be minimal "as there had been few cases in which a claim has been successfully brought” (Brown 2007, p. 325). In fact, only thirty cases reached the courts and only ten of those were proven (Department for Trade and Industry 2003, para. 3.29). As a result, the CCA 1974 was amended by the CCA 2006 which removed the $£ 25,000$ limit and replaced the extortionate credit bargains provisions with the new "unfair relationship” provisions in ss. 140A-C. Important for the purposes of this article is the change made to the coverage of the new unfair relationship provisions which, by virtue of s. $140 \mathrm{~A}(5)$, do not include regulated mortgage contracts (Brown 2007, p. 329; Burrows 2013, para. 5.33; Dixon 2014, p. 438).

The second provision which also impacts upon first legal mortgages is s. 126 CCA 1974 which imposes an obligation on the mortgagee to obtain a court order in order to enforce the agreement. According to the original s. 16(6D) CCA 1974 (inserted by the Financial Services and Markets Act 2000 (Regulated Activities) Order 2001, now repealed) regulated mortgage agreements were not exempt from s. 126 CCA 1974. Since 1 April 2014, s. 126 has been 
amended so as to make specific reference to regulated mortgage agreements (s. 3(3) Financial Services and Markets Act 2000 (Regulated Activities) (Amendment) Order 2014). Hence, any first legal mortgage created after 31 October 2004 can only be enforced through a court order.

This reform altered one of the fundamental tenets of land law which is that the first legal mortgagee has an inherent right to possession arising out of the legal estate granted to them (McFarlane et al. 2012, p. 1153; McAuslan 2009a, pp. 35-38). That right is not dependent upon default and previously could be exercised extra-judicially. First legal mortgagees were not therefore obliged to seek the permission of the court prior to taking possession. In practice, however, it was common for possession to be obtained by virtue of a court order as the lender was keen to avoid the possibility of prosecution under the criminal law should violence be used in the act of taking possession (Criminal Law Act 1977, s.6 and the Protection from Eviction Act 1977). It is the case also that mortgagees have little to fear from the court process given that, by virtue of s. 36 AJA 1970, they will either obtain possession or payment off the arrears. The extension of s. 126 CCA 1974 to regulated mortgage contracts therefore affected very little change in practice.

Overall, the CCA 1974 was not intended nor did it offer any significant extra protection to first legal mortgagors. The regulatory distinction made between first and second mortgages and the complexity it created was subject to heavy criticism (Citizens Advice 2007; Nield 2010), but it has been reformed as a result of the Financial Services Act 2012. On 1 April 2014, the FCA became responsible for regulating second charge mortgages, bringing regulated mortgage agreements and second mortgages under one regulator and subject to the FSMA 2000 by 2016. However, this will do little to alter the distinction that is made between first and second mortgages. As the FCA suggests,

the Government's overall approach has been to keep the scope of consumer credit regulation broadly the same. There are no significant differences in the types of loan agreement that are exempt from being "regulated agreements". ${ }^{5}$

The new consumer credit regime for second mortgages is contained in the FCA's specialist Consumer Credit Sourcebook (CONC) while regulated mortgage contracts will continue to be subject to the Mortgages and Home Finance Conduct of Business Sourcebook (MCOB). The FCA's consultation document CP14/20 sets out the changes but their impact on judicial attitudes or land law rules will be indirect, for example, by making second charge lenders

\footnotetext{
${ }^{5}$ http://www.fca.org.uk/firms/firm-types/consumer-credit/scope
} 
subject to MCOB 13 and thereby reducing the need for their mortgagors to make use of time orders under the CCA 1974 (para. 3.87). The complexity apparent in the regulation of consumer credit agreements under the CCA 1974 (and the FSMA 2000) should not obscure the fact that first legal mortgages were largely and will continue to be excluded from its operation and in turn, excluded from the enhanced protection it affords to second mortgagors. The justification for this is that first legal mortgages are adequately regulated by the public law regime, to which this article now turns.

\section{The Conception of the Mortgagor in Public Law}

By virtue of the Financial Services and Markets Act 2000, “regulated mortgage contracts” (defined in PERG 4.4) created after 31 October 2004 are subject to regulation by the FCA. While much of this article has bemoaned the lack of consumer protection afforded to the first legal mortgagor, it is clear that the public law aspects of regulation adopt a strong consumer protection approach. While this is to be welcomed, it does mean that the mortgagor cannot bring an action against their mortgagee but must instead rely on the regulator to monitor and police the behaviour of mortgagees. As previous experience has demonstrated in relation to the former regulator, the Financial Services Authority (FSA), such reliance may be misplaced, as made clear by HM Treasury (2010, para. 1.3),

the monolithic financial regulator, the Financial Services Authority, had too broad a remit and insufficient focus to identify and tackle issues early and it relied too heavily on a "tick box" approach to regulation.

The introduction of the FCA, however, has brought with it a new more interventionist approach to regulating the conduct of mortgagees so for now, the assumption must be that the problems that beset the FSA will not now afflict the FCA. Initial signs, however, are not promising. Under the Unfair Terms in Consumer Contract Regulations 1999 (UFTCCR 1999, as amended by the Unfair Terms in Consumer Contract Regulations (Amendment) 2001), for example, the FCA (as a “qualifying body” under the UFTCCR 1999, Sch. 1) has responsibility for assessing the fairness of terms in mortgages. In addition to publishing guidance on best practice (FSA 2008; FSA 2012a), the FCA conducts reviews of contractual terms in specific areas and investigates referrals from consumers. ${ }^{6}$ The impact of this

\footnotetext{
${ }^{6}$ For more information see http://www.fca.org.uk/firms/being-regulated/unfair-contracts.
} 
regulatory power however appears minimal with the FCA having received ten UFTCCR 1999 "undertakings"7 from mortgagees since October $2006 .^{8}$

More promising from a consumer protection point of view is that the regulator has sought to regulate aspects of the mortgage relationship including mortgage exit fees (FSA 2007) and arrears charges (FSA 2010) as well as seeking views on the meaning of fairness when changes are made to a regulated mortgage contract (FCA 2014a). It has also completed recently its comprehensive review of the mortgage market, known as the Mortgage Market Review (MMR). In an effort to ensure "continued access to mortgages for the great majority of customers who can afford it, while preventing a return to the poor practices that we saw in the past,"9 the FCA implemented in April 2014 the final rules arising out of the rather protracted review process which began in 2009 (FSA 2012).

The changes focus on responsible lending (particularly as regards affordability checks) and arrears management (particularly charges imposed on borrowers in arrears). While the impact of these changes cannot yet be assessed, they form part of the FCA's overarching objective which is to ensure that mortgagors are "treated fairly" (FSA 2006). Central to this goal is the FCA's main regulatory instrument MCOB which has been amended following the MMR. ${ }^{10}$ This requires mortgagees, for example, when deciding whether to grant mortgage finance, to take into account the mortgagor's ability to repay the loan (MCOB 11.6.2), that possession should be undertaken only "where all other reasonable attempts to resolve the position have failed” (MCOB 13.3.2AR(6)) and that the equivalent of at least two months' arrears must have accumulated before court proceedings should be initiated (MCOB defines "arrears" as a shortfall equivalent to two or more regular payments in the accumulated total payments actually made by the borrower).

The most recent and wide ranging initiative to be introduced into the public law regime is the MCD, introduced in February 2014. Although the original White Paper on the integration of

\footnotetext{
${ }^{7}$ The FCA define an undertaking as 'a written agreement from a firm to take certain actions. For example, the firm may give an undertaking that it will not rely on an unfair term' see http://www.fca.org.uk/firms/being-regulated/unfair-contracts/faqs.

${ }^{8}$ http://www.fca.org.uk/firms/being-regulated/unfair-contracts/library\#agreements

${ }^{9}$ http://www.fca.org.uk/firms/firm-types/mortgage-brokers-and-home-financelenders/mortgage-market-review.

${ }^{10}$ See http://fshandbook.info/FS/html/FCA.
} 
EU mortgage markets (Commission of the European Communities 2007) was “overtaken by events” (Nield 2010, p. 611), the Commission published the proposal for the MCD in March 2011 (Commission of the European Communities 2011). Following its adoption in February 2014, the UK government has until March 2016 to implement it. The MCD is of particular relevance given the Commission's preference for the nomenclature of “consumer” rather than "mortgagor" and its efforts to enhance consumer protection within mortgage markets across Europe. By virtue of the MCD, Member States must ensure that, "before concluding a credit agreement, the creditor makes a thorough assessment of the consumer's creditworthiness" (Article 18) and that the creditor "provides the consumer with the personalised information needed to compare the credits available on the market, assess their implications and make an informed decision on whether to conclude a credit agreement” (Article 14).

The MCD applies equally to first and second mortgages (hence the FCA's new role as the regulator of second mortgages) but this does not mean that first and second mortgages will be treated in the same manner in all respects. They will simply both be subject to the changes that prove necessary as a result of the implementation of the MCD. Evidence in terms of the likely success of the MCD in terms of affecting real change, however, is somewhat underwhelming given that it received a lukewarm response from the FSA and the FCA, the suggestion being that the regulatory regime within the UK is sufficient, particularly given that it is tailored to the specific needs of the UK market (FSA 2011). The FCA's proposals for implementing the MCD (FCA 2014) will impact less upon first legal mortgages than on second mortgages but changes will include ensuring that vulnerable customers with a payment shortfall are treated fairly and appropriately.

It seems clear therefore that the public law measures designed to regulate the first legal mortgage conceive of the mortgagor as a consumer deserving of protection against unscrupulous and unfair treatment at the hands of their lender. If such measures were successful in terms of creating a level playing field between mortgagors and mortgagees then the private law regime might be considered justified in conceiving of the mortgagor as a party with equal bargaining power. However, as the following section will demonstrate, a "well functioning consumer credit market” (HM Treasury 2013, para. 1.1) has yet to be achieved which means that the private law conception of the mortgagor remains inappropriate and at times, works against the best efforts of the regulator. Nowhere is this more evident than in relation to the issue of possession. 


\section{Challenging Private Law Assumptions}

The summary of the private law regulatory framework offered above reveals that it has two principal aims, namely, to protect the security of the mortgagee and to allow the mortgagor an unfettered right to redeem (Gray and Gray 2009, pp. 715-746; see also the "no clogs or fetters” on the equity of redemption case law, including Fairclough $v$ Swan Brewery Ltd [1912] AC 565 HL). Beyond this, it imposes few if any substantive requirements upon the parties to the mortgage, leaving them largely free to negotiate the terms of their agreement, subject only to general contractual principles and judicial oversight (Bright 2000). While there is the occasional interference with the fundamental adherence to the principle of freedom of contract, land law ultimately demonstrates a preference for the commercial interests of the mortgagee (Fox 2007, pp. 88-92). This approach is based upon an assumption that the parties entered the contract on a voluntary basis and were free to negotiate its terms. Reliance upon the freedom of contract principle, however, is misplaced within the mortgage relationship for two reasons. In the first instance, lenders tend to impose, in respect of first acquisition mortgages, non-negotiable standard terms. These include terms which impose liability upon the mortgagor for all costs involved in the mortgagee's enforcement of their security.

Secondly, despite improvements in the quality of information provided to borrowers since the introduction of the regulator (including, for example, the introduction of Key Facts Illustration documents and information to borrowers in arrears regarding charges) and further moves to enhance such information (including the European Standardised Information Sheet recommended by the MCD) information regarding the individual possession policies of mortgagees is not and will not be made available to prospective borrowers. Citizens Advice (2007, para. 3.44), for example, has called for the publication by all FCA regulated mortgagees of their arrears management policies and has emphasised that it is "important for consumers to be able to compare between firms if good practice is to affect their purchasing decisions.” This is of particular concern given the inconsistency apparent in the arrears management practices of mortgagees, with some much more likely to seek possession immediately upon two months default than others (Citizens Advice 2007; Ford and Wallace 2009; Whitehouse 2008a; Whitehouse 2008b). As Shelter (2008, p. 4) notes, the outcome is that "customers have for too long had to suffer a variable range of treatment if they fall into arrears, depending on who their lender is.” 
Given that a mortgagor rarely has the ability to influence the contractual terms, regardless of the mortgage product or mortgagee chosen, therefore, it would seem that the rhetoric of competition has not become the practice within the mortgage market despite the best efforts of the FCA. In a number of cases this lack of informed choice can prove crucial in the borrower's attempts to avoid possession. The reason for this derives from the self-fulfilling and oddly logical nature of the repossession process. To summarise, a mortgagor who contracts with a mortgagee who is quick to seek possession in the courts will find themselves liable for the costs of that hearing. These will be added to the security but, given that the only means of avoiding possession is to demonstrate an ability to repay the mortgage, increasing it can only work to the disadvantage of the mortgagor. Add to this the fact that district judges have until now been unwilling to suspend possession orders under s. 36 AJA 1970 for the recommended period of the remaining term of the mortgage (Whitehouse 2011), in part because of the fees and costs imposed on the mortgagor while in arrears, it becomes apparent why more information regarding the possession policies of mortgagees might assist in enhancing choice as well as avoiding possession. While there seems to be little prospect of mortgagees being made to publicise their arrears and possessions policies, recent moves by the FCA have the potential to impact directly on the possession process.

The Intersection of the Public Law and Private Law Regimes: the Possession Process The rules arising out of the Mortgage Market Review (FSA 2009a; FSA 2010; FSA 2010a; FSA 2012a) include greater responsibility on the part of mortgagees to assess the mortgagor's ability to afford the mortgage (FSA 2011a, chapter 3), and the abolition of charges where an agreement has been reached with a mortgagor for the repayment of arrears (FSA 2011a, chapter 6; FSA 2011b, chapter 4; now implemented in MCOB 12.4.1AE). Underlying this review is the implication that, "no longer can lenders be self-interested players within the neoliberal market model” (Nield 2010, p. 629).

These moves, although piecemeal, have the potential to assist some households in their attempt to avoid possession by addressing the complex interrelationship between s. 36 of the AJA 1970, the costs of the hearing and the charges imposed by mortgagees. For example, the refusal by district judges to suspend possession orders for the remaining term of the mortgage as a result of the interest and fees charged while the mortgagor remains in arrears could be reversed by the FCA's move to ban monthly arrears administration charges and to ensure that such charges recover the cost of administering them rather than being treated as a source of 
profit (FSA 2010, para 4.2; House of Commons Treasury Committee 2009, paras 33-40). The impact of these changes has yet to be assessed and while they are to be welcomed, the House of Commons Treasury Committee (2009, p. 3) has already voiced its concern in respect of "the seemingly leisurely approach of the FSA in terms of completing its mortgage arrears review and enforcing possible breaches in the rules in the area of mortgage arrears...”. It would seem, therefore, that while the FCA has recognised the need for greater protection, the momentum in respect of achieving that reform has been rather slow.

The hope is that the public law mechanisms (including MCOB) will assist some mortgagors in avoiding possession but if they are threatened with the loss of home, they must still rely on a land law system (including s. 36 AJA 1970) that demonstrates a preference for the freedom of contract model rather than the consumer protection model. This is despite evidence to suggest that mortgagors do not have sufficient information to allow them to exercise informed choice, are not able to negotiate the terms of their agreement and are subject to onerous terms that place them at a significant disadvantage (Stewart 1996, p. 49). It is these very factors, however, suggestive as they are of market and information failures, which justifies a change not only in how the s. 36 discretion is exercised but a fundamental change in perception.

\section{Why is the Mortgagor Deserving of Consumer Protection?}

In making the case for a paradigm shift in how land law conceives of the mortgagor, it would, in an ideal world, be preferable to make the case for the reinstatement of their status as citizens. However, with a grudging acceptance of the seemingly irreversible privatisation of housing or hopefully as an expedient and effective remedy to the ills of the mortgage market, this article will instead make the case for the mortgage to be viewed through the lens of consumer protection. In calling for greater protection for mortgagors in respect of the first legal mortgage, however, this article is wary of claims relating to the commodification of housing. The obvious danger in calling for a more consumerist approach is that if purchasing residential property is viewed as equivalent to the purchase of other commodities, then why should mortgagors receive greater protection against the loss of their home? The aim, however, in equating certain aspects of the purchase of residential property with other consumer products is simply to reverse the situation, prevalent within the current private law regulatory framework, which means that mortgagors purchasing land receive less protection than a consumer using their second mortgage to purchase, say, a car. The argument, therefore, 
is that mortgagors deserve at least as much protection as would normally attach to the status of consumer.

Unlike other consumer transactions, however, the mortgage is deserving of special attention and tailored regulation for two reasons. The first is that, as consumer transactions go, it has its very own special and unique characteristics, as Nield (2010, p. 617) notes, “in contrast to other financial products, the mortgage (like other credit) is not always seen as the product being bought and sold but as a means to an end. The focus is then on the asset purchased.” The implication of this is that mortgagors are less likely to be aware of the content and consequences of the mortgage contract, a claim supported by Citizens Advice (2007, para. 2.5), "evidence suggests that there is a significant proportion of consumers that start out with little or no understanding of even the most fundamental aspects of a mortgage or secured loan agreement.” There appears, therefore, to be a case for greater protection of the mortgagor in the initial stages of the mortgage relationship. This has been recognised by the MCD which requires Member States to promote measures designed to lead to better educated consumers of mortgage products (MCD, Article 6).

The second reason as to why the purchase of a residential property is deserving of special treatment concerns its qualities, not as a commodity, but as a "home”. Recent research by Fox, Bright and others has attempted to define the elusive qualities that make a house a “home” (Bright 2010; Fox 2007; Gurney 1999; Malpass 1999; Radin 1982; Saunders 1990; Smith 1994). Although a difficult task given that it operates as, "an intangible relationship between people and the places in which they dwell; it is not visible nor accurately measurable” (Dovey 1985, p. 53), "home” is comprised of a unique set of qualities including privacy, security, identity and order. It is these qualities which mean that the possession of a home should not be treated as equivalent to the possession of a car. As Nield (2010, p. 613) suggests, “secured lending places the mortgagor's home in jeopardy and thus warrants the highest safeguards against predatory lending and enforcement practices.” It is these qualities also which justify the need to reform the private law regulation of the mortgage relationship so as to invest it with the key elements of a consumer protection approach.

What type of “Consumer”?

For a self-confessed land lawyer it has proven difficult to find a concise and unambiguous definition of what is meant by “consumer” and “consumer law” (Nagarajan 2007; Ramsay 2006, p. 9). The European Commission defines “consumer” as a natural person who is acting 
for purposes which are outside his trade, business or profession (2008). The FCA, however, offers several definitions of different “consumers” including "retail” consumers "buying financial products or services for their own use or benefit (e.g. travel insurance, ISAs, or mortgages), either directly or through a regulated firm” (FCA 2011). As Cartwright (2011, p. 1) rightly notes this should not come as a surprise given that consumers are "a heterogeneous rather than a homogeneous group.” There appear, for example, to be numerous and at times conflicting rationales for consumer law that make use of different modes of regulation. These range from neo-liberal reliance upon competition as a regulating force to paternalistic models founded on "government knows best". They all appear, however, to be driven in the main by certain key objectives, namely, “access, choice, safety, information, equity, redress and representation” (National Consumer Council 1996) although the emphasis placed on each key element and how best to achieve it differs. Access and choice, for example, are important within approaches concerned with social exclusion while information occupies a central role within economic rationales. Each model will also have a particular conception of the consumer that it is trying to facilitate, ranging from the informed, rational and responsibilised consumer to the vulnerable individual prone to rash decision-making who is deserving of paternalism (Nagarajan 2007; Ramsay 2006; Ramsay 2012).

Given the range of households who seek out mortgage finance for home purchase and the concerns that abound in relation to low income consumers in particular (Stewart 1996, p. 27; Munro et al. 2005), it is argued that mortgagors should be given the opportunity to become responsibilised consumers but should not necessarily be assumed to be so. As Cowan et al (2012, p. 190) suggest, the expansion of home ownership so as to include lower income households coupled with the argument that creditor interests required protection in order to ensure a steady flow of mortgage finance,

raises questions about the extent to which owners (or, more accurately, buyers who remain subject to a mortgage, often for decades, before becoming unencumbered owners) can be viewed as autonomous consumers, free of the structural constraints that inhibit financial decision-making concerning credit.

The private law framework should not lose sight of the fact that individual households have been actively encouraged by successive governments to enter into home ownership and for many, this necessitates obtaining mortgage finance from powerful institutional lenders who are "repeat players" both within the mortgage market and related legal processes. The aim 
therefore is to settle on some middle ground between the "responsibilised” (Nagarajan 2007; Ramsay 2006, p. 13) or “empowered” consumer (Legal Services Consumer Panel 2013) and the vulnerable ill-informed consumer deserving of paternalism (Cartwright 2011; for a criticism of such paternalism see Nield 2010, p. 630).

One obvious issue that arises here concerns the mortgagor's responsibility for informing themselves about the mortgage and for ensuring that they do not borrow amounts beyond their means. While the rhetoric of recent regulatory moves has been as much about responsible borrowing as it has about responsible lending (Cowan et al. 2012, pp. 192-193; Nield 2010; Ramsay 2006, p. 13), behavioural economists might question the extent to which mortgagors actively "choose" to enter into home ownership, not least given the rhetoric promoted by successive governments over recent decades. To claim that mortgagors enter the mortgage contract voluntarily and that they should, therefore, accept a degree of responsibility should it turn out to be an unfair exchange is far too simplistic a view. As Nield (2010, p. 617) suggests, "there is growing recognition that a mortgagor's decision to borrow may not be made on solely rational grounds but is a more complex process that is also influenced by factors that have inspired the development of behavioural economics.”

\section{Reform: Some Practical Proposals}

The attempt to illustrate what a private law consumer protection model of regulation might look like is assisted by the fact that one already exists in the form of the approach adopted towards second mortgages. While the different treatment afforded to second mortgages has always been justified according to the higher risk faced by those entering into such agreements, the distinction with first legal mortgagors is no longer so sharply drawn. There is, admittedly, considerable evidence to demonstrate that sub-prime mortgagees are more likely to partake in inequitable and unconscionable behaviour towards their mortgagors. It is clear, for example, that they are more likely to initiate court action for possession at an earlier date than institutional mortgagees (AdviceUK et al. 2009, p. 10). Shelter offers evidence of subprime lenders flouting current rules by imposing disproportionate charges upon mortgagors in arrears (Rashleigh and Marshall 2010, pp. 24-25). Research undertaken by Citizens Advice (2007) and the FSA's own review of the regulation of the mortgage market (FSA 2008a, FSA 2009a) also found inconsistent compliance with MCOB, particularly within the sub-prime sector. More recent research has highlighted continuing non-compliance on the part of these lenders, particularly in relation to the Protocol (Bright and Whitehouse 2014, p. 24). 
The distinction between prime and sub-prime mortgagees, however, has been undermined by substantial evidence, over recent decades, regarding the irresponsible lending practices of high street lenders including, of course, the banking crisis (FCA 2011, para. 1.1; FSA 2009; Nield 2010, p. 264). There is evidence, for example, which demonstrates that institutional mortgagees participated in irresponsible lending practices prior to the banking crisis of 2008, lending money to individuals that could not be justified according to even the most basic of affordability checks or which increased greatly the risk of mortgagors falling into arrears. During 2003-2007, for example, some mortgagees became more willing to lend on the basis of higher loan to value ratios and income multiples (FSA 2009a, chapter 2). As Ford and Wallace (2009, p. 12) note, a range of factors led, perhaps inevitably, to unsustainable levels of home ownership,

the highly competitive and lightly regulated UK mortgage market interacted with individuals’ predisposition to own their homes and government policy to extend home ownership, offering specialist products, lending to more marginal borrowers, and extending lending at higher multiples of income and value. All of these factors increased the risk of borrowers defaulting on their loans.

This suggests therefore that the exemption of first legal mortgagors from the consumer credit provisions can no longer be justified. In expanding the power of the courts in relation to first mortgages to re-open unfair agreements or to impose time orders, it would be important to ensure that the imbalance in the bargaining strengths of the parties to the mortgage is recognised and addressed. District judges should also be prepared to award costs against the mortgagee, particularly where they have failed to comply with pre-action requirements (AdviceUK et al. 2009) and, given the FCA’s reforms in respect of arrears charges, to make use of longer periods for the suspension of possession orders. This will of course, not save those mortgagors who are unable to repay their normal monthly payments and arrears within a reasonable period but it will ensure a greater degree of consistent and equitable treatment.

\section{Conclusions}

The exemption of first legal mortgages from the majority of the provisions of the Consumer Credit Act 1974 has been a matter of concern for government (Department for Business, Innovation and Skills 2009, para. 1.2.2; Ministry of Justice 2009), consumer organisations (Citizens Advice 2009) and scholars (Brown 2007) for a number of years. This concern derives from the perception that the CCA 1974 regime was much more protective than the 
protection offered to first legal mortgagors. The assumption must be that these mortgages are adequately regulated under the FSMA and that the FCA will ensure that mortgagors are treated "fairly" but, this removes the ability of mortgagors to bring an action on their own behalf, leaving them reliant instead on a regulator that still has to prove itself. As Citizens Advice (2008, p. 7) note, the difficulty faced by regulators in monitoring compliance within the mortgage market "is that the regulator... is always at a distance and is only likely to pick up problems after they have occurred.” Given the FSA's failure to regulate mortgagees effectively in recent years (House of Commons Treasury Committee 2009, p. 3), significant improvements will have to be made by the FCA in enforcement procedures.

The failure of previous provisions to impact significantly upon the arrears management practices of mortgagees is of particular concern given the fear that current levels of possessions have been subdued as a result of a stagnant housing market and low interest rates. Wallace and Ford (2009, p. 139), for example, found that the recent fall in the number of claims for possession was due largely to current housing market conditions and "memories of the last recession and the fallout from the US sub-prime crisis.” The question therefore is, what will happen to mortgage arrears and possessions as market conditions change? Government policy ambitions and lenders' forbearance strategies have been largely synchronised since summer 2008. Once these key dimensions diverge, will current regulatory practice be sufficient to sustain current practice in limiting possessions? There is a distinct possibility that, depending on housing market improvement, possessions have merely been postponed rather than avoided (Ford and Wallace 2009, p. 139).

The concern expressed in this article is that if the private law regime does not harmonise its approach with that of the public law regime by treating the mortgagor as a consumer then the introduction of reforms such as those proposed by the FCA and the European Commission will prove ineffective in responding to this "ticking time bomb" in mortgage possessions. Cowan (2011, p. 20) argues that "labels are important and identifying occupiers as consumers implies a host of rights and obligations that suggest activity and choice on the part of the occupier (which might not be possible or appropriate).” What this article has hopefully demonstrated is that labels are indeed important but that the nomenclature of consumer denotes not only, as Cowan suggests, choice, rationality and sovereignty. It reflects also a 
concern to protect the individual household against excessive power, oppressive terms and unfair treatment.

The hope is that the change in the legal conception of the mortgagor to one of consumer, particularly in respect of the possession process, will address many of the obstacles that are currently preventing mortgagors from receiving fair and consistent treatment. Cultural shifts of this kind take time but, the law of mortgage has demonstrated a capacity to change its conception of the mortgagor and there are promising signs of progress within both housing policy and financial services regulation. The hope is that this conceptual transformation occurs in time to deter the predicted explosive rise in mortgage possessions. 


\section{References}

AdviceUK, Citizens Advice and Shelter (2009). Turning the Tide? Available at http://www.citizensadvice.org.uk/index/campaigns/policy_campaign_publications/evidence_r eports/er_consumerandebt/turning_the_tide_.htm.

Atiyah, P. S. (1995). An Introduction to the Law of Contract. Oxford: Clarendon Press.

Ball, M. (1983). Housing Policy and Economic Power: The Political Economy of Owner Occupation. London: Methuen.

Boddy, M. (1980. The Building Societies (Macmillan Press: London, 1980); Cleary, E.J., The Building Society Movement. London: Elek Books.

Bright, S. (1998). Of Estates and Interests: A Tale of Ownership and Property Rights. In S. Bright \& J. Dewar (Eds.), Land Law: Themes and Perspectives (pp. 529 - 546). Oxford: Oxford University Press.

Bright, S. (2000). Winning the Battle Against Unfair Contract Terms. Legal Studies, 20, 331352.

Bright, S. J. (2010). Dispossession for Arrears: The Weight of Home in English Law. In L. Fox O’Mahony \& J. A. Sweeney, (Eds.), The Idea of Home in law: Displacement and Dispossession. London: Ashgate.

Bright, S. and Whitehouse, L. (2014) Information, Advice and Representation in Housing Possession Cases. Available at http://perma.cc/U2KC-H8FQ.

Brown, S. (2007). The Consumer Credit Act 2006; Real Additional Mortgagor Protection. Conveyancer, Jul/Aug, 316-339.

Burrows, A. (2013). English Private Law. Oxford: Oxford University Press.

Cartwright, P. (2011). The Vulnerable Consumer of Financial Services: Law, Policy and Regulation. Available at

http://www.nottingham.ac.uk/business/businesscentres/crbfs/documents/researchreports/paper 78.pdf.

Citizens Advice (2007). Set Up To Fail: CAB Clients’ Experience of Mortgage and Secured Loan Arrears Problems available at 
http://www.citizensadvice.org.uk/index/policy/policy_publications/er_credit_debt/set_up_to_ fail.htm.

Citizens Advice (2008). Mortgage Arrears Protocol: Response by Citizens Advice to the Civil Justice Council. London: Citizens Advice.

Citizens Advice (2009). Mortgage Remedies (Possession and Sale) Review Lines of Inquiry: Response by Citizens Advice to the Ministry of Justice. London: Citizens Advice.

Commission of the European Communities. (2007). White Paper on the Integration of EU Mortgage Credit Markets. COM(2007) 807.

Commission of the European Communities. (2008). Directive 2008/48/EC on credit agreements for consumers and repealing Council Directive 87/102/EEC.

Commission of the European Communities. (2011). Proposal for a Directive of the European Parliament and of the Council on Credit Agreements Relating to Residential Property. COM (2011) 142 final.

Cowan, D. (2011). Housing Law and Policy. Cambridge: Cambridge University Press.

Cowan, D., Fox O’Mahony, L., \& Cobb, N. (2012). Great Debates: Property Law. Hampshire: Palgrave Macmillan.

Cowan, D., \& McDermont, M. (2006). Regulating Social Housing: Governing Decline. Oxford: Routledge-Cavendish.

Craig, P. (1986). The House that Jerry Built? Building Societies, the State and the Politics of Owner-Occupation. Housing Studies, 1, 87-96.

Daunton, M. J. (1987). A Property-Owning Democracy? London: Faber and Faber.

DCLG, (March 2012). Reinvigorating Right to Buy and One for One. London: Department for Communities and Local Government.

Department for Trade and Industry (2003). Fair, Clear and Competitive - The Consumer Credit Market in the 21st Century. White Paper CM 6040.

Department for Business, Innovation and Skills (2009). A Better Deal for Consumers: Delivering Real Help Now and Change for the Future. Cm 7669. 
Dixon, M. (1999). Sorry, We’ve Sold Your Home: Lenders and Their Possessory Rights. Cambridge Law Journal, 58, 265-293.

Dixon, M. (2014). Modern Land Law. Abingdon: Routledge.

Dovey, K. (1985). Home and Homelessness. In I. Altman \& C. M. Werner (Eds.), Home Environments. New York: Plenum Press.

Dworkin, R. (1991). Taking Rights Seriously. London: Duckworth.

Fairest, P.B. (1980). Mortgages. London: Sweet \& Maxwell.

FCA. The Perimeter Guidance Manual (PERG).

FCA (2011). Approach to Regulation. Available at

http://www.fsa.gov.uk/pubs/events/fca_approach.pdf.

FCA (2014). Implementation of the Mortgage Credit Directive and the new regime for second charge mortgages. Consultation Paper. CP14/20.

FCA (2014a). Fairness of changes to mortgage contracts. Discussion Paper. DP14/2.

Ford, J., \& Burrows, R. (1999). The Costs of Unsustainable Home Ownership in Britain. Journal of Social Policy, 28, 305-330.

Ford, J., \& Quilgars, D. (2001). Failing Home Owners? The Effectiveness of Public and Private Safety-Nets. Housing Studies, 16, 147-162.

Ford, J., \& Wallace, A. (2009). Uncharted Territory? Managing Mortgage Arrears and Possessions. London: Shelter.

Forrest, R., \& Murie, A. (1984). Right to Buy? Issues of Need, Equity and Polarisation in the Sale of Council Houses. Bristol: School for Advanced Urban Studies.

Forrest, R., \& Murie, A. (1990). Residualisation and Council Housing: A Statistical Update Bristol: School for Advanced Urban Studies.

Forrest, R., \& Williams, P. (1984). Commodification and Housing: Emerging Issues and Contradictions. Environment and Planning, 16, 9, 1163 - 1180.

Fox, L. (2007). Conceptualising Home: Theories, Law and Policies. Oxford: Hart. 
FSA (2006). Treating Customers Fairly - Towards Fair Outcomes for Consumers. London: Financial Services Authority.

FSA (2007). Statement of good practice on mortgage exit administration fees (MEAFs). London: Financial Services Authority.

FSA (2008). Fairness of terms in consumer contracts: a visible factor in firms treating their customers fairly. London: Financial Services Authority.

FSA (2008a). Mortgage Effectiveness Review: Arrears Findings. Research Report Project no. 30895. London: Financial Services Authority.

FSA (2009). The Turner Review: A Regulatory Response to the Global Banking Crisis. London: Financial Services Authority.

FSA (2009a). Mortgage Market Review. Discussion Paper 09/3. London: Financial Services Authority.

FSA (2010). Mortgage Market Review: Arrears and Approved Persons. Policy Statement 10/9 (June 2010). London: Financial Services Authority.

FSA (2010a). Mortgage Market Review: Distribution and Disclosure. Consultation Paper 10/28. London: Financial Services Authority.

FSA (2011). The Mortgage Credit Directive: Key Considerations. London: Financial Services Authority.

FSA (2011a). Mortgage Market Review: Proposed Package of Reforms. CP11/31. London: Financial Services Authority.

FSA (2011b). Mortgage Market Review: Responsible Lending. Consultation Paper 10/16. London: Financial Services Authority.

FSA (2012). Finalised Guidance: Unfair Contract Terms: Improving Standards in Consumer Contracts. London: Financial Services Authority.

FSA (2012a). Mortgage Market Review: Feedback on CP11/31 and Final Rules. London: Financial Services Authority.

Gray, K., \& Gray, S. F. (2009). Elements of Land Law. Oxford: Oxford University Press. 
Gurney, C. (1999). Pride and Prejudice: Discourses of Normalisation in Public and Private Accounts of Home Ownership. Housing Studies, 14, 2, 163-185.

Haley, M. (1997). Mortgage Default: Possession, Relief and Judicial Discretion. Legal Studies, 17, 483.

Hilton, M. (2003). Consumerism in 20 $0^{\text {th }}$-Century Britain. Cambridge: Cambridge University Press.

House of Commons Treasury Committee (2009). Mortgage Arrears and Access to Mortgage Finance. HC 767.

HM Treasury (2010). A New Approach to Financial Regulation: Summary of Consultation Responses. London: HM Treasury.

HM Treasury (2013). A New Approach to Financial Regulation: Transferring consumer credit regulation to the Financial Conduct Authority. London: HM Treasury.

Hunter, C., \& Nixon, J. (1998). Better a Public Tenant Than a Private Borrower Be: The Possession Process and the Threat of Eviction. In D. Cowan (Ed.), Housing: Participation and Exclusion (pp. 84-106). Aldershot: Ashgate.

Jones, C., \& Murie, A. (2006). The Right to Buy: Analysis and Evaluation of a Housing Policy. Oxford: Blackwell.

Kemeny, J. (1981). The Myth of Home-Ownership. London: Routledge \& Kegan Paul.

Kleinman, M. P., \& Whitehead, C. M. E. (1988). British Housing since 1979: Has the System Changed? Housing Studies, 3, 3-19.

Legal Services Consumer Panel (2013). Empowering Consumers. Available at http://www.legalservicesconsumerpanel.org.uk/publications/research_and_reports/documents/ ChoosingUsingBP1.pdf.

Maitland, F. W. (1936). Equity: A Course of Lectures. Cambridge: Cambridge University Press.

Malpas, J.E. (1999). Place and Experience: A Philosophical Topography. Cambridge: Cambridge University Press, 1999.

Malpass P., \& Murie, A. (1994) Housing Policy and Practice. London: MacMillan. 
McAuslan, P. (2009). Mortgage Arrears: The Repossession Crunch. Journal of International Banking and Finance Law, 3, 137.

McAuslan, P. (2009a). Whose mortgage is it anyway? Producers, consumers and the law in the UK mortgage market. Available at http://www.gla.ac.uk/media/media_129711_en.pdf.

McFarlane, B., Hopkins, N. \& Nield, S. (2012). Land Law: Text, Cases, and Materials. Oxford: Oxford University Press.

Ministry of Justice (2009). Mortgages: Power of Sale and Residential Property. Consultation Paper. CP55/09.

Ministry of Justice (2014). Mortgage and Landlord Possession Statistics Quarterly: January to March 2014. London: Ministry of Justice.

Munro, M., Ford, J., Leishman, C., \& Karley, N.K. (2005). Lending to Higher Risk

Borrowers: Sub-Prime Credit and Sustainable Home-Ownership. York: Joseph Rowntree Foundation.

Murie, A. (1998). Secure and Contented Citizens? Home-ownership in Britain. In A. Marsh \& D. Mullins (Eds), Housing and Public Policy. Buckingham: Open University Press.

Nagarajan, V. (2007). Reconceiving Regulation: Finding a Place for the Consumer. Competition and Consumer Law Journal, 15, 1, 93-107.

National Consumer Council (1996). A Code of Practice for Home Loans. London: National Consumer Council.

Nield, S. (2010). Responsible Lending and Borrowing: Whereto Low-Cost Home Ownership? Legal Studies, 30, 610-632.

Radin, M. J. (1982). Property and Personhood. Stanford Law Review, 34, 957.

Ramsay, I. (2006). Consumer Law, Regulatory Capitalism and the "New Learning” in Regulation. Sydney Law Review, 28, 9, 9-35, at p. 13.

Ramsay, I. (2012). Consumer Law and Policy. Oxford: Hart.

Rashleigh, B., \& Marshall, T. (2010). Charged Out. Roof, March/April, 24-25.

Saunders, S. P. (1990). A Nation of Home Owners. London: Allen \& Unwin. 
Scott, C., \& Black, J. (2000) Cranston's Consumers and the Law. London: Butterworths.

Shelter (2008). Consultation Response: Shelter's Response to the Civil Justice Council's Consultation on the Mortgage Arrears Protocol. London: Shelter.

Simpson, A. W. B. (1964). An Introduction to the History of the Land Law. Oxford: Oxford University Press.

Smith, G. (1994). The Essential Qualities of a Home. Journal of Environmental Psychology, 14, 31-46.

Smith, R. J. (1979). The Mortgagee’s Right to Possession - The Modern Law. Conveyancer 266.

Smith, S. J. (2005). Banking on Housing? Speculating on the Role and Relevance of Housing Wealth in Britain. Project Report. Durham: Durham University. Available at http://dro.dur.ac.uk/71/.

Smith, P., \& Swann, D. (1979). Protecting the Consumer: An Economic and Legal Analysis Oxford: Martin Robertson.

Stephens, M., Dailly, M., \& Wilcox, S. (2008). Developing Safety Nets for Home-Owners. York; Joseph Rowntree Foundation.

Stephens, M., \& Quilgars, D. (2007). Managing Arrears and Possessions. Housing Finance, 5, $1-14$.

Stewart, A. (1994). Rethinking Housing Law: A Contribution to the Debate on Tenure. Housing Studies, 9, 2, 263-279.

Stewart, A. (1996). Rethinking Housing Law. London: Sweet \& Maxwell.

Whitehouse, L. (1997). The Right to Possession. The Need for Substantive Reform. In P. Jackson \& D. C. Wilde, (Eds.), The Reform of Property Law (pp. 150 - 176). Aldershot: Ashgate.

Whitehouse, L. (1998). The Impact of Consumerism on the Home Owner. In D. Cowan (Ed.), Housing: Participation and Exclusion (pp. 126-146). Aldershot: Ashgate. 
Whitehouse, L. (1998a). The Home Owner: Citizen or Consumer? In S. Bright \& J. Dewar (Eds.), Land Law: Themes and Perspectives (pp. 183 - 205). Oxford: Oxford University Press.

Whitehouse, L. (2009). The Mortgage Arrears Pre-Action Protocol: An Opportunity Lost. $M L R, 72,793-814$.

Whitehouse, L. (2011). A Longitudinal Analysis of the Mortgage Repossession Process 19952010: Stability, Regulation and Reform. In S. Bright (Ed.), Modern Studies in Property Law (pp. 151-174). Oxford: Hart Publishing.

Whitehouse, L. (2011a). The Malleability of the Law of Mortgage. In C. Twigg-Flesner \& G. Villalta-Puig (Eds.), The Boundaries of Commercial and Trade Law (pp. 51-74). Munich: Sellier 